Gontar, N.N. \& Sukhova, M.V. (2021). Features of the transformation of the budget of the Krasnodar Krai in the period of the pandemic for 2020. Management as a science of complex development. Collection of Scientific Articles. European Scientific e-Journal, 6 (12), 45-56. Hlučín-Bobrovníky: “Anisiia Tomanek” OSVČ. Гонтарь, Н.Н., Сухова, М.В. (2021). Особенности трансформации бюджета Краснодарского края в период пандемии за 2020 год. Management as a science of complex development. Collection of Scientific Articles. European Scientific e-Journal, 6 (12), 45-56. Hlučín-Bobrovníky: “Anisiia Tomanek” OSVČ.

DOI: $10.47451 /$ jur2021-04-002

EOI: $10.11244 /$ jur2021-04-002

The paper is published in Crossref, Internet Archive, Google Scholar, Academic Resource Index ResearchBib, JGate, ISI, CiteFactor, ICI, eLibrary databases.

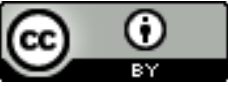

Nina N. Gontar

Associate Professor

Candidate of Sciences in Jurisprudence (PhD)

Faculty of Training Specialists for the Judicial System

Russian State University of Justice

St Petersburg, Russia

E-mail: ninagontar@mail.ru

Margarita V. Sukhova

Master's degree student

Faculty of Training Specialists for the Judicial System

Russian State University of Justice

St Petersburg, Russia

E-mail: ninagontar@mail.ru

\title{
Features of the transformation of the budget of the Krasnodar Krai in the period of the pandemic for 2020
}

\section{Abstract:}

One of the most important tools for regulating social and economic development is the budget occupying a central place in the financial system of the state. With the help of budget funds, the levels of social and economic development of territories are levelled, financing of industries and spheres of the national economy is provided, budget funds are directed to the development of priority areas of economic development. The object of this study was the Krasnodar Krai budget for 2020. The study purpose was to analyze the features of the budget structure of the Krasnodar Krai during the pandemic in 2020. During the study, comparative, historical and analytical methods were applied, which helped to obtain the necessary analytical materials and evaluate them. Based on the study, it was concluded that the highest index in income during the pandemic was the tax on personal income and the lowest-the tax on mining. The Krasnodar Krai budget for 2020 received more revenue than planned. Consequently, there was a positive trend and a gradual increase in the revenue part of its budget.

Keywords:

Krasnodar Krai, budget transformation, COVID-19, budget management. 
Нина Николаевна Гонтарь

Аоцент, кандидат юридических наук

Факультет подготовки специалистов Аля судебной системы

Российский государственный университет правосудия

Санкт-Петербург, Россия

E-mail: ninagontar@mail.ru

Маргарита Викторовна Сухова

магистрант

Факультет подготовки специалистов Аля судебной системы

Российский государственный университет правосудия

Санкт-Петербург, Россия

E-mail: ninagontar@mail.ru

\section{Особенности трансформации бюджета Краснодарского края в период пандемии за 2020 год}

\section{Аннотачия:}

ОАним из важнейших инструментов, обеспечивающих регулирование социальноэкономического развития общества, явцяется бюджет, который занимает центрацьное место в финансовой системе государства. С помощью бюджетных средств происходит выравнивание уровней социально-экономического развития территорий, обеспечивается финансирование отраслей и сфер народного хозяйства, бюджетные средства направляются на развитие приоритетных направлений развития экономики. Объектом Аанного исследования являлся бюджет Краснодарского края за 2020 год. Целью исследования явАя ся анализ особенностей структуры бюджета Краснодарского края в период пандемии за 2020 года. В ходе исследования были применены сравнительный, исторический и аналитический методы, которые способствовали получению необходимых анаАитических материалов и их оценке. На основании исследования был сделать вывоА, что наибольший

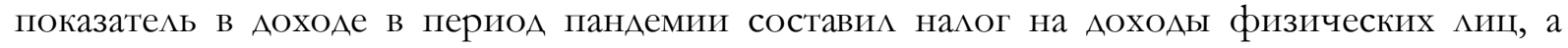
наименьшей - налог на добычу полезных ископаемых. В бюджет Краснодарского края за период 2020 года поступило Аоходов больше, чем планировалось. Следовательно, проявилась положительная динамика и постепенное увеличении доходной части бюджета Краснодарского края.

Kлючевые слова:

Краснодарский край, трансформация бюджета, COVID-19, управление бюджетом.

\section{Introduction}

One of the most important tools to regulate social and economic development is the budget occupying a central place in the financial system of the state. With the help of budget funds, the levels of socio-economic development of territories are levelled, financing of industries and spheres of the national economy is provided, 
budget funds are directed to the development of priority areas of the economy. In modern conditions of Russia, the centre of gravity in the management of social and economic processes is shifting to the level of regions, and, so possible ways to solve problems in the economic and social development of the country lie precisely at the regional level (The Concept of the Budget, 2018). In this regard, regional budgets' role in solving the problems of economic and social development of territories in the era of the COVID-19 pandemic is increasing.

The object of this study was the budget of the Krasnodar Territory for 2020.

The study purpose was to analyze the features of the budget structure of the Krasnodar Territory during the pandemic in 2020.

Based on the goal, the tasks, which were to be solved in the course of the study, were developed:

- define the concept of the budget, taking into account the peculiarities of the Russian economic school;

- $\quad$ consider the budget as a legal category;

- $\quad$ analyze the budget of the Krasnodar Krai for 2020;

- conclude the specifics of changes in budget management during the pandemic in 2020, which allowed the subject of the Russian Federation to maintain its leading position among the regions of the country.

During the study, comparative, historical and analytical methods were applied, which helped to obtain the necessary analytical materials and evaluate them.

To achieve the goal and solve the tasks set, the Budget Code of the Russian Federation, legislative documents and statistical data of Krasnodar Krai published on the Internet on the official websites of the regional government and other portals, as well as research materials of budgeting specialists E.Y. Grachev, E.D. Sokolov, T.V. Yermoshina and E.I. Kosynkina were used.

\section{Features of the concept of budget in the Russian Federation}

A budget is a financial plan for a particular entity, whether it is a single person, a family, an organization, or the state as a whole. Such a plan is established for a certain period. The concept of 'budget' is also included in the Russian legislation. A budget is a form of formation and expenditure of funds intended for the financial support of the tasks and functions of the state and local self-government (Budget Code of the Russian Federation, 1998).

As an instrument of state regulation in the field of formation and development of the economic and social structure, the budget is considered in two aspects: 
economic and legal. As an economic category, the budget reflects the system of economic relations, the participants of which are on the one hand, the state, and on the other - enterprises, organizations and society as a whole. The objectives of the budget of this category are distribution and redistribution of the total social product and national income; formation of a centralized fund of funds that are distributed for the financial support of the tasks and functions of the state. The essence of such a budget is realized through its functions:

- $\quad$ distributional (redistribution of GDP);

- regulatory (state regulation and economic stimulation);

- $\quad$ stimulating (financial support of the budgetary sphere and implementation of the state's social policy);

- controlling (control over the formation and use of centralized funds of funds) (The Concept of the Budget, 2018).

E.Y. Gracheva and E.D. Sokolova define the budget in its economic aspect as "the financial basis for the functioning of the state and municipalities, the central link of the financial system of society, with which all its links are connected" (Gracheva, 2020).

Considering the budget as a legal category, it should note that the budget acts as a financial plan of the state, the general purpose of which is to create conditions for the effective development of the economy, solving national tasks, and strengthening the defence capability with the help of financial resources.

The analysis of expenditures and revenues of various regions of the Russian Federation remains relevant for many years, as the role of regional and local budgets increases. The role of regional budgets of the Russian Federation subjects in economic and social development is as follows.

First, the totality of finances in the budgets of the Russian Federation regions allows the state regional authorities (representative and executive) to have a financial base for the exercise of their powers following the Constitution of the Russian Federation. Thanks to regions' budgets, monetary funds of administrative-territorial entities are formed, which can ensure the implementation of tasks of a common purpose for them.

Second, the formation and concentration of monetary resources in regional budgets provide an opportunity for the Russian Federation subjects to fully exercise financial and economic independence in spending funds on their social and economic development. In turn, regional budgets allow the authorities to ensure the 
systematic development of infrastructure in these subjects (educational institutions, medical institutions, cultural and art institutions, housing and road facilities).

Third, there is an alignment of the levels of economic and social development of the territories. For this purpose, regional programs of economic and social development of the regions are formed and implemented for the improvement of villages and cities, the development of the road network, the maintenance of historical and cultural institutions, etc. (Kosynkina, Yermoshina, 2015).

Thus, all subjects of the Russian Federation have their budget. That is why the study of the budget of those regions of the Russian Federation that have generally successfully overcome the pandemic crisis is particularly relevant. This article presents an analysis of the budget management of one of the most successful subjects - the Krasnodar Krai.

\section{Analysis of the budget of the Krasnodar Krai for $\mathbf{2 0 2 0}$}

Krasnodar Krai is a subject of the Russian Federation, which is located in the southwestern part of the North Caucasus and is part of the Southern Federal District. The population for 2021 is 5,689,538 people. The Krasnodar Krai has a favourable geostrategic position and a well-developed transport infrastructure.

One of the main branches of the economy of the Krasnodar Territory is the tourism sector, which is rapidly developing in this subject. The coast of the Black and Azov Seas, as well as the mountainous and steppe regions of the krai attract a large number of not only Russian citizens, but also foreign persons, and every year more and more.

After the 22nd Olympic Winter Games were held in Sochi in 2014, the infrastructure and hotel facilities were significantly improved and developed, sports stadiums and other security facilities were built, the quality of services was improved. The level of professional training of working personnel was significantly increased too. All this contributed to a large influx of tourists and significantly increased the contribution of tourism to the Krasnodar Krai GRP amounted to $14.2 \%$. In the Russian Federation as a whole, the contribution of tourism to GDP was at the level of $1.3 \%$.

The COVID-19 epidemic, which began in December 2019 in China, and is now a pandemic, has significantly increased the value and demand for domestic resorts and health resorts, the main of which continues to be the Krasnodar Territory. External factors that contributed to the development of the tourism market in this subject of the Russian Federation are the ban for citizens to leave their country of 
residence and the closure of international borders. These restrictions have contributed to a large influx of tourists to the south of the Russian Federation.

According to statistics, as of December 2020, the Krasnodar Territory received 11.5 million tourists in the context of the pandemic. This index is the highest among the subjects of the Russian Federation. The resort fee, in turn, amounted to more than 370 million rubles. For two years, from mid-2018 to mid-2020, the number of funds and resources, which came to the regional budget from the payment of the resort fee, amounted to 373.2 million rubles.

Statistical data showed that in the consolidated budget, the revenues of the Krasnodar Krai are formed from tax and non-tax revenues, which for the 12 months of 2020 amounted to $279,779.89$ million rubles and were fulfilled by $104 \%$. Also, the formation comes from gratuitous receipts, which amounted to 95,291.26 million rubles. Total budget revenues were allocated 374,346.16 million rubles, while $387,083.86$ million rubles were executed, which was $103 \%$. Federal taxes and fees amounted to corporate income tax $-61,760.41$ million rubles, while $60,026.74$ million rubles were assigned; excise taxes - 29,324.64 million rubles; personal income tax $-97,523.59$ million rubles. Other tax revenues amounted to 29,396.66 million rubles. Regional taxes were:

- $\quad$ corporate property tax - 36,200.05 million rubles;

- transport tax $-8,009.01$ million rubles,

- $\quad$ although 7,210.17 million rubles were assigned.

Local taxes and fees amounted to a land tax of 8,096.29 million rubles, property tax of individuals - 3,690.21 million rubles. Grants, subventions and subsidies were fulfilled by an average of 100\% (Budget Expenditures, 2021).

\section{Discussion}

The budget policy of the Krasnodar Territory showed a sufficiently high level in 2020, which is reflected in the overall index of the gross regional product (GRP). However, to study the features of managing the budget potential of the region within the state, it is necessary to study the following two important positions:

1. Analysis of the ratio of index of the trend in the development of industry structures compared with the share index in regional and state significance.

2. Search for index (markers) of the effectiveness of the budget policy of the state region, taking into account the trend index in the development of industry structures. 
The solution of these issues will help create a more competent analytical method of the response and behaviour of the budget department to crises of the state and world level in the future.

\section{Conclusion}

After analyzing the presented statistics, it is necessary to conclude that the highest index in income during the pandemic was the personal income tax, and the lowest was the mineral extraction tax.

The Krasnodar Krai budget for 2020 received more revenue than planned. Therefore, we can say about the positive dynamics and a gradual, but steady increase in the revenue part of the Krasnodar Krai budget. According to item 5 of Article 26.13 of the Federal Law On the General Principles of the Organization of Legislative (Representative) and Executive Bodies of State Power of the Subjects of the Russian Federation of October 6, 1999, No. 184-FZ, the budget of the subject of the Russian Federation separately provides for income directed to the financial support of the exercise of powers, and subventions to ensure the exercise of powers, as well as the corresponding expenses carried out at the expense of these incomes and subventions.

Expenditures of the budget of the Russian Federation subject are the funds paid from the budget, except for those that are sources of financing the budget deficit. According to statistics for 2020, expenditures on national issues were fulfilled by $88 \%$ amounted to $25,084.39$ million rubles out of $28,483.52$ million rubles assigned; social policy amounted to 99,801.8 million rubles; physical culture and sports is $11,602.50$ million rubles out of $11,945.34$ million rubles assigned; mass media is 1,042.92 million rubles; servicing of state (municipal) debt is 3,014.68 million rubles.

Spending on national defence, national security and law enforcement, environmental protection, culture and cinematography, and health care, on average, was executed by $95-97 \%$. The budget expenditures of the Krasnodar Krai for the national economy amounted to 60,529.64 million rubles out of the designated 65,998.13 million rubles; for housing and communal services, 19,441.41 million rubles out of the designated 22,061.17 million rubles. Inter-budget transfers of a general nature to the budgets of the budget system of the Russian Federation amounted to 0.00 rubles in 2020, although it was planned to fulfil 8.81 million rubles. Total budget expenditures of the Krasnodar Territory were assigned 406,514.63 million rubles, while 388,021.64 million rubles were executed. Based on this, we can 
conclude that the budget expenditures for the 12 months of 2020 were realized by 95\% (Budget Expenditures, 2021).

After analyzing the presented statistics, we can conclude that the largest index in budget expenditures is education, and the smallest is national defence. Compared to the last year 2019, spending on education decreased by $1 \%$, on health care increased by 3\%. In the Krasnodar Krai budget for 2020, fewer expenses were spent than planned and more than $70 \%$ of expenses were fulfilled.

\section{References:}

About the approval of the main directions of the budget and tax policy of the municipality of Krasnodar for 2021 and for the planning period of 2022 and 2023. Resolution No. 4604 of October 28, 2020.

Baydetskaya, E.A. (2019). Assessment of the budget and tax policy of the Krasnodar Territory for 2019-2021. Bulletin of the Academy of Knowledge, 2 (31), 266-270.

Budget Code of the Russian Federation. 1998. Article 6. (in Russian)

Budget Expenditures (2021). Portal of Open Budget of the Krasnodar Krai.

$\begin{array}{llll}\text { Retrieved } \quad \text { March } & \text { 2021, from }\end{array}$

https://openbudget23region.ru/analitika/ispolnenie-

byudzheta/raskhody/raskhody-byudzheta (in Russian)

Budget Revenues (2021). Portal of Open Budget of the Krasnodar Krai. Retrieved

March 5, 2021, from https://openbudget23region.ru/analitika/ispolneniebyudzheta/dokhody/dokhody-byudzheta (in Russian)

Gracheva, E.Y. (2020). Financial law: textbook for secondary vocational education. 5th ed. Moscow: Norma, INFRA-M. (in Russian)

Kosynkina, E.I. \& Yermoshina, T.V. (2015). Actual problems of forming budgets of the subjects of the Russian Federation. Contentus, 4 (33). - Saransk: Information Mordovia. (in Russian)

On the Regional Budget for 2020 and for the Planning Period of 2021 and 2022 (2019). Law of the Krasnodar Krai, No. 4200-KZ of December 23, 2019, as amended on December 11, 2020. Retrieved March 8, 2021, from https://docs.cntd.ru/document/561648600 (in Russian)

The Concept of the Budget. (2018). Portal of Open Budget of the Krasnodar Krai Retrieved March 1, 2021, from https://openbudget23region.ru/obyudzhete/obshchaya-informatsiya-o-byudzhete/ponyatie-byudzheta (in Russian) 
The Draft Law of the Krasnodar Krai "On the Implementation of the Regional Budget for 2020" (2019). Portal of Open Budget of the Krasnodar Krai. Retrieved March 6, 2021, from https://openbudget23region.ru/obyudzhete/dokumenty/ministerstvo-finansov-krasnodarskogo-kraya/1216proekt-zakona-krasnodarskogo-kraya-ob-ispolnenii-kraevogo-byudzheta-za2020-god (in Russian)

\section{Appendix}

Table 1. Regional budget revenues for 2020 by budget revenue classification codes (Appendix 1 to the Law of the Krasnodar Krai "On the Implementation of the Regional Budget for 2020")

\begin{tabular}{|c|c|c|}
\hline № & Title & $\begin{array}{l}\text { Executed, } \\
\text { million rubles }\end{array}$ \\
\hline 1. & Federal Service for Supervision of Natural Resources Management & 114.12 \\
\hline 2. & Federal Forestry Agency & 0.33 \\
\hline 3. & $\begin{array}{l}\text { Federal Service for Supervision of Communications, Information } \\
\text { Technologies and Mass Communications }\end{array}$ & 0.4 \\
\hline 4. & Federal Treasury & $20,797.7$ \\
\hline 5. & Federal Service for Supervision of Transport & 39.14 \\
\hline 6. & $\begin{array}{l}\text { Federal Service for Supervision of Consumer Rights Protection and } \\
\text { Human Welfare }\end{array}$ & 0.05 \\
\hline 7. & Federal Antimonopoly Service & 0.74 \\
\hline 8. & $\begin{array}{l}\text { Ministry of the Russian Federation for Civil Defense, Emergency } \\
\text { Situations and Elimination of Consequences of Natural Disasters }\end{array}$ & 3.1 \\
\hline 9 . & Federal Service of the National Guard of the Russian Federation & 0.004 \\
\hline 10. & Federal Tax Service & 191,310 \\
\hline 11. & Ministry of Defence of the Russian Federation & 0.15 \\
\hline 12. & Ministry of Internal Affairs of the Russian Federation & $2,641.3$ \\
\hline 13. & Ministry of Justice of the Russian Federation & 0.65 \\
\hline 14. & Federal Service for State Registration, Cadastre and Cartography & 639 \\
\hline 15. & Federal Bailiff Service & 0.03 \\
\hline 16. & Prosecutor General's Office of the Russian Federation & 0.003 \\
\hline 17. & Legislative Assembly of the Krasnodar Krai & 0.38 \\
\hline 18. & Administration of the Krasnodar Krai & 243.9 \\
\hline 19. & $\begin{array}{l}\text { Regional Energy Commission - Department of Prices and Tariffs of } \\
\text { the Krasnodar Krai }\end{array}$ & 6.67 \\
\hline
\end{tabular}




\begin{tabular}{|c|c|c|}
\hline 20. & $\begin{array}{l}\text { Department of Consumer Sphere and regulation of the Alcohol } \\
\text { market of the Krasnodar Krai }\end{array}$ & 95.8 \\
\hline 21. & Ministry of Finance of the Krasnodar Krai & $33,139.6$ \\
\hline 22. & Department of Industrial Policy of the Krasnodar Krai & 5.66 \\
\hline 23. & $\begin{array}{l}\text { Department of Financial and Budgetary Supervision of the } \\
\text { Krasnodar Krai }\end{array}$ & 3.17 \\
\hline 24. & Department of Civil Registration of the Krasnodar Krai & 14.75 \\
\hline 25. & Control and Accounting Chamber of the Krasnodar Krai & 5.1 \\
\hline 26. & $\begin{array}{l}\text { The Commissioner for Human Rights in the Krasnodar Krai and his } \\
\text { office }\end{array}$ & 0.02 \\
\hline 27. & Commissioner for Children's Rights in the Krasnodar Krai & 0.014 \\
\hline 28. & Ministry of Economy of the Krasnodar Krai & 55.58 \\
\hline 29. & $\begin{array}{l}\text { Ministry of Agriculture and Processing Industry of the Krasnodar } \\
\text { Krai }\end{array}$ & $4,430.3$ \\
\hline 30. & $\begin{array}{l}\text { Ministry of Civil Defence and Emergency Situations of the } \\
\text { Krasnodar Krai }\end{array}$ & 10.34 \\
\hline 31. & Department of Property Relations of the Krasnodar Krai & $2,402.15$ \\
\hline 32. & Election Commission of the Krasnodar Krai & 4.35 \\
\hline 33. & $\begin{array}{l}\text { Ministry of Fuel and Energy Complex and Housing and Communal } \\
\text { Services of the Krasnodar Krai }\end{array}$ & $2,555.24$ \\
\hline 34. & Department of Construction of the Krasnodar Krai & $2,261.5$ \\
\hline 35. & $\begin{array}{l}\text { Ministry of Education, Science and Youth Policy of the Krasnodar } \\
\text { Krai }\end{array}$ & $4,741.6$ \\
\hline 36. & Ministry of Culture of the Krasnodar Krai & 199.97 \\
\hline 37. & Department of Information Policy of the Krasnodar Krai & 0.02 \\
\hline 38. & Ministry of Health of the Krasnodar Krai & $13,523.14$ \\
\hline 39. & Ministry of Physical Culture and Sports of the Krasnodar Krai & 200.67 \\
\hline 40. & Ministry of Labor and Social Development of the Krasnodar Krai & 29,357 \\
\hline 41. & $\begin{array}{l}\text { Department of Architecture and Urban Planning of the Krasnodar } \\
\text { Krai }\end{array}$ & 0.5 \\
\hline 42. & $\begin{array}{l}\text { Department of Cossack Affairs, Military Affairs and work with Pre- } \\
\text { conscription Youth of the Krasnodar Krai }\end{array}$ & 9.46 \\
\hline 43. & Department of Veterinary Medicine of the Krasnodar Krai & 1.67 \\
\hline 44. & $\begin{array}{l}\text { Department for Supervision in the Construction sector of the } \\
\text { Krasnodar Krai }\end{array}$ & 19.16 \\
\hline 45. & $\begin{array}{l}\text { Department for Ensuring the activities of Magistrates of the } \\
\text { Krasnodar Krai }\end{array}$ & 51.15 \\
\hline 46. & $\begin{array}{l}\text { Department of Investment and Development of Small and Medium- } \\
\text { sized enterprises of the Krasnodar Krai }\end{array}$ & 798.3 \\
\hline 47. & State Housing Inspectorate of the Krasnodar Krai & 10.9 \\
\hline 48. & Ministry of Transport and Road Management of the Krasnodar Krai & $4,669.44$ \\
\hline
\end{tabular}




\begin{tabular}{|r|l|r|}
\hline 49. & $\begin{array}{l}\text { Ministry of Resorts, Tourism and Olympic Heritage of the Krasnodar } \\
\text { Krai }\end{array}$ & 108.65 \\
\hline 50. & Ministry of Natural Resources of the Krasnodar Krai & 396.27 \\
\hline 51. & $\begin{array}{l}\text { Department for Regulation of the Contract System of the Krasnodar } \\
\text { Krai }\end{array}$ & 0.025 \\
\hline 52. & $\begin{array}{l}\text { Department of Informatization and Communication of the } \\
\text { Krasnodar Krai }\end{array}$ & 10.7 \\
\hline 53. & $\begin{array}{l}\text { The Commissioner for the Protection of the Rights of Entrepreneurs } \\
\text { in the Krasnodar Krai and his office }\end{array}$ & 0.01 \\
\hline
\end{tabular}

Таблица 2. Expenditures of the regional budget for 2020 according to the departmental structure of expenditures of the regional budget (Appendix 2 to the Law of the Krasnodar Krai “On the Execution of the Regional Budget for 2020”)

\begin{tabular}{|c|c|c|}
\hline № & Title & Execution \\
\hline 1. & Legislative Assembly of the Krasnodar Krai & $97.4 \%$ \\
\hline 2. & Administration of the Krasnodar Krai & $97.0 \%$ \\
\hline 3. & $\begin{array}{l}\text { Regional Energy Commission - Department of Prices and Tariffs of } \\
\text { the Krasnodar Krai }\end{array}$ & $96.9 \%$ \\
\hline 4. & $\begin{array}{l}\text { Department of Consumer Sphere and regulation of the Alcohol } \\
\text { market of the Krasnodar Krai }\end{array}$ & $89.5 \%$ \\
\hline 5. & Ministry of Finance of the Krasnodar Krai & $86.8 \%$ \\
\hline 6. & Department of Industrial Policy of the Krasnodar Krai & $99.3 \%$ \\
\hline 7. & $\begin{array}{l}\text { Department of Financial and Budgetary Supervision of the Krasnodar } \\
\text { Krai }\end{array}$ & $96.8 \%$ \\
\hline 8. & Department of Civil Registration of the Krasnodar Krai & $96.3 \%$ \\
\hline 9 . & Control and Accounting Chamber of the Krasnodar Krai & $98.7 \%$ \\
\hline 10. & $\begin{array}{l}\text { The Commissioner for Human Rights in the Krasnodar Krai and his } \\
\text { office }\end{array}$ & $99.6 \%$ \\
\hline 11. & The Commissioner for Children's Rights in the Krasnodar Krai & $98.8 \%$ \\
\hline 12. & Ministry of Economy of the Krasnodar Krai & $97.8 \%$ \\
\hline 13. & Ministry of Agriculture and Processing Industry of the Krasnodar Krai & $97.7 \%$ \\
\hline 14. & $\begin{array}{l}\text { Ministry of Civil Defense and Emergency Situations of the Krasnodar } \\
\text { Krai }\end{array}$ & $95.9 \%$ \\
\hline 15. & Department of Property Relations of the Krasnodar Krai & $99.3 \%$ \\
\hline 16. & Election Commission of the Krasnodar Krai & $99.6 \%$ \\
\hline 17. & $\begin{array}{l}\text { Ministry of Fuel and Energy Complex and Housing and Communal } \\
\text { Services of the Krasnodar Krai }\end{array}$ & $80.6 \%$ \\
\hline 18. & Department of Construction of the Krasnodar Krai & $87.0 \%$ \\
\hline
\end{tabular}




\begin{tabular}{|c|c|c|}
\hline 19. & $\begin{array}{l}\text { Ministry of Education, Science and Youth Policy of the Krasnodar } \\
\text { Krai }\end{array}$ & $99.4 \%$ \\
\hline 20. & Ministry of Culture of the Krasnodar Krai & $98.9 \%$ \\
\hline 21. & Department of Information Policy of the Krasnodar Krai & $99.6 \%$ \\
\hline 22. & Ministry of Health of the Krasnodar Krai & $98.8 \%$ \\
\hline 23. & Ministry of Physical Culture and Sports of the Krasnodar Krai & $98.5 \%$ \\
\hline 24. & Ministry of Labor and Social Development of the Krasnodar Krai & $97.9 \%$ \\
\hline 25. & $\begin{array}{l}\text { Department of Architecture and Urban Planning of the Krasnodar } \\
\text { Krai }\end{array}$ & $81.9 \%$ \\
\hline 26. & $\begin{array}{l}\text { Department of Cossack Affairs, Military Affairs and work with Pre- } \\
\text { conscription Youth of the Krasnodar Krai }\end{array}$ & $99.7 \%$ \\
\hline 27. & Department of Veterinary Medicine of the Krasnodar Krai & $96.5 \%$ \\
\hline 28. & $\begin{array}{l}\text { Department for Supervision in the Construction sector of the } \\
\text { Krasnodar Krai }\end{array}$ & $99.7 \%$ \\
\hline 29. & $\begin{array}{l}\text { Department for Ensuring the activities of Magistrates of the } \\
\text { Krasnodar Krai }\end{array}$ & $98.0 \%$ \\
\hline 30. & $\begin{array}{l}\text { Department of Investment and Development of Small and Medium- } \\
\text { sized enterprises of the Krasnodar Krai }\end{array}$ & $97.1 \%$ \\
\hline 31. & State Housing Inspectorate of the Krasnodar Krai & $98.3 \%$ \\
\hline 32. & Ministry of Transport and Road Management of the Krasnodar Krai & $95.1 \%$ \\
\hline 33. & $\begin{array}{l}\text { Ministry of Resorts, Tourism and Olympic Heritage of the Krasnodar } \\
\text { Krai }\end{array}$ & $62.8 \%$ \\
\hline 34. & Ministry of Natural Resources of the Krasnodar Krai & $83.9 \%$ \\
\hline 35. & $\begin{array}{l}\text { Department for Regulation of the Contract System of the Krasnodar } \\
\text { Krai }\end{array}$ & $96.9 \%$ \\
\hline 36. & $\begin{array}{l}\text { Department of Informatization and Communication of the Krasnodar } \\
\text { Krai }\end{array}$ & $96.5 \%$ \\
\hline 37. & $\begin{array}{l}\text { The Commissioner for the Protection of the Rights of Entrepreneurs } \\
\text { in the Krasnodar Krai and his office }\end{array}$ & $96.5 \%$ \\
\hline
\end{tabular}

